\title{
Otto Hintze's response to the crisis of historicism
}

\author{
A resposta de Otto Hintze para a crise do historicismo
}

\section{Marcelo Durāo Rodrigues da Cunha ${ }^{a}$ \\ E-mail: marceloduraocunha@gmail.com https://orcid.org/0000-0001-6585-6836 (D)}

a Instituto Federal do Espirito Santo, Unidade Vitória, Vitória, ES, Brasil

\section{ABSTRACT}

This article aims to shed light on the theoretical contributions of the historian Otto Hintze to the intellectual context experienced by German historical science in the late nineteenth and the first half of the twentieth century. To do so, I proceed from the assumption that Hintze's positions were constituted as an attempt to answer the crisis of historicism: namely, the collapse of trust in the Western-centered concept of history in modern times. From that previous definition, I argue that his individual ethics derived from what I describe as his two main theoretical contributions, developed to overcome such a crisis: the desacralization of modern state politics and his scientific reconceptualization of historicism. Finally, I claim that both the crisis of historicism itself and the responses offered by Hintze to overcome it remain largely present to reflect on some of the challenges professional historiography still faces in the twenty-first century.

\section{KEYWORDS}

Otto Hintze; Historicism; Crisis of Historicism

\section{RESUMO}

Este artigo tem o objetivo de trazer à tona as contribuições teóricas oferecidas pelo historiador Otto Hintze ao contexto intelectual vivido pela ciência histórica alemã nas décadas finais do Oitocentos e na primeira metade do século XX. Para tanto, parto do pressuposto de que as posições de Hintze se constituíram em grande medida como uma tentativa de resposta à crise do historicismo: o colapso da crença sustentada por parte da burguesia letrada alemã, no sentido "singular coletivo", adquirido pelo conceito de história na modernidade ocidental. À luz dessa definição preambular, busco compreender a ética individual de Hintze como uma posição derivada do que defendo terem sido as duas principais contribuições desse historiador para o debate em tela: a dessacralização da política do Estado moderno e a sua reconceitualização científica do historicismo. Finalmente, defendo que tanto a crise do historicismo em si, quanto as respostas oferecidas por Hintze para a sua superação permanecem presentes para refletirmos a respeito de alguns desafios vivido pela historiografia profissional ainda no século XXI.

PALAVRAS-CHAVE

Otto Hintze; Historicismo; Crise do Historicismo 


\section{Introduction}

For a long time, historians and historians of historiography associated nineteenth and twentieth century German historical science solely with Leopold von Ranke and a theoretically naive type of historical knowledge limited by its narrow interest in politics, diplomacy and the history of European states. Although it is not completely mistaken to affirm the clear links between this tradition of historical thought with a history from above (of great men, national heroes, and the prominence of the European great powers), such a superficial view contributed to create a simplistic regard towards German historiography which, from Ranke to Friedrich Meinecke, is, in many cases, still seen by some historians as a simple-minded and politically incautious kind of historicism.

Being largely a construction of the Historical Social Science that emerged in Germany during the 1960s and the 1970s, ${ }^{1}$ this simplistic view of the pre-World War II German historical science has, in the last few decades, been challenged by numerous studies preoccupied with a more pluralistic outlook not only on Rankean historiography alone, but also the twentieth century intellectual heirs of this classical version of historicism. In the wake of these historiographical incursions, historians of German historiography were able to produce a great variety of works that unveil the complexity of the Rankean legacy itself and to yield a large volume of research which revealed the theoretical nuances of historicism as well as its relevance to present day historical thought. ${ }^{2}$

A good example of this trend is the place that a name like Otto Hintze (1861-1940) have come to occupy in the discussions of international historiography in the last few decades. More than a mere maintainer of nineteenth century historiographical premises, Hintze has come to be seen by interpreters of his work as a historian who-at a time of deep crisis in historical knowledge 
and in the Western scientific thought as a whole-offered complex and updated responses to the challenges faced by the historical discipline in the early decades of the twentieth century. ${ }^{3}$ From his embrace of interdisciplinarity, his appeal to expand the subject matter of history and his efforts to renew the theoretical perspectives of traditional historiography, Hintze has become an inescapable reference for those concerned with better grasping the contours of the historical discipline during Germany's Wilhelmine and Interwar periods. ${ }^{4}$ Therefore, his legacy has also been revisited by interpreters who regard his work as containing roots of the social history, which was widely practiced by post-1945 Western historiography.

In line with these historiographical tendencies, my objective in this article is to bring to light some of Hintze's theoretical contributions, by dealing especially with two elements which I believe are central to understanding his historiographical legacy: (1) the desacralization of modern state politics, which is operated by Hintze's theoretical interpretation of Western modernity, and (2) Hintze's rational definition of the concept of historicism that led to what he identified as a "healthy" and "volitional" type of decisiveness, developed under Max Weber's influence during the 1920s.

Hence, I claim that the development of the historian's theoretical position was a particular reaction to how I will define the "crisis of historicism": a collapse of trust in the modern "collective singular" Western-centered concept of history, which affected parts of the German literate bourgeoisie and certain representatives of German historical thought of the Interwar era. Finally, having demonstrated such hypothesis, I will provide basis for the idea that both the crisis of historicism itself and the responses offered by Hintze to overcome it remain largely relevant to reflect on some of the challenges historiography in the twentieth-first century faces still.

\begin{abstract}
3 - An English language synthesis of Hinze's intellectual biography and his main historiographical contributions has recently appeared in Leonard S. Smith's The Expert's Historian (2017).

4 - Important
contributions have
also recently been
made by Wolfgang
Neugebauer (2015),
who-though not
dealing directly with
the problems of his-
toricism-pays special
attention to Hinze's
precocious inclination
towards comparative
and global historical
outlooks.
outlooks.
\end{abstract}




\section{The crisis of historicism or the dissolution of the modern concept of history}

Everything has individuality and is a law to itself, everything is relative and in a state of flux: then give me the point where I can stand. How can we emerge from this anarchy of values?

(MEINECKE 1959, p. 377).

When writing these words in 1923, the historian and Hintze's personal friend, Friedrich Meinecke, refers to the instability that defined the culture of his time and which he believed had emerged with even greater vehemence in the early decades of the twentieth century. "Relativity", "anarchy of values", and "state of flux", were symptoms of what Meinecke identified as the ambiguous development of the German tradition of historical thought in the last two centuries.

Meinecke believed that despite having possessed the virtue of liberating modern man from the old universalist dogmatism of the pre-modern era, historicism with its emphasis on the historicity of the world, had pointed to the transience of all things over time, revealing the finite, limited and relative character of values and human institutions throughout history. Meinecke's diagnosis arose as a response to what the theologian Ernst Troeltsch had earlier defined as the "crisis of historicism": "the dissolution of the state, law, morality, art, and religion in the flow of becoming historical", which was largely responsible for the atmosphere of uncertainty experienced during that era (TROELTSCH 1922, p. 573).

Troeltsch, Meinecke and Hintze debated these issues during their weekly walks in the Berlin district of Dahlem at least since the beginning of the Great War in 1914, when they began teaching at the University of Berlin. Even with Troeltsch's sudden death in 1923, the drawbacks of the theologian's crisis diagnosis remained alive in Meinecke and Hintze's meditations, as well as in the theoretical reflections of many of their academic contemporaries over the following decades. 
However, what exactly did Meinecke, Troeltsch, and Hintze refer to while dealing with a so-called crisis of historicism? What was the meaning of their quest for a stable point amid this alleged relativity brought about by historical thought? Not having been restricted to the decades around 1900, the debate on the meaning of historicism and its alleged crisis, continued to fuel many controversies within and outside the German academic world, staying alive in several discussions among theoreticians and philosophers of history in the twenty-first century.

A good example is offered by the intensity with which this theme returned to the intellectual debates of historians and philosophers during the 1980s, the 1990s and the 2000s, ${ }^{5}$ when a series of works examined the problems of historicism within the context of the crisis created by postmodern thought. Taking advantage of insights that emerged in those decades and enhancing some of the reflections produced in such discussions, the Dutch historian Herman Paul introduced a series of important redefinitions on what has been understood by international historiography as a crisis of historicism in the past few years. Basing his analysis on the interpretations of Friedrich Jaeger and Wolfgang Hardtwig, Paul sees the so-called classical version of historicism as a cultural phenomenon which underlay the beliefs of nineteenth century German bourgeoisie in moral values and notions of continuity, providence, and historical progress that were the basis of their identity and selfimage. Thus, historicism was not a matter of Rankean historical methods alone, but of "historical identifications", or modes of identity formation in which historical narratives played crucial roles (PAUL 2010b, p. 1).

Regarding national history, nineteenth century historicism provided literate German culture with a justification for its belief in the notion of stability and meaning in the continuity of its historical course (PAUL 2008, p. 5-6). Between the end of the nineteenth and the beginning of the twentieth century, however, the radicalism of experiences brought forth by war and industrialization were accompanied by feelings of fragmentation

\section{5 - $\quad$ The crisis of historicism appears as the central theme in the work of the fol- lowing authors: An- nette Wittkau (1992); Charles R. Bambach (1995); Wolfgang Bi- alas (1996); Reinhard Laube (2004) and Otto Gerhard Oexle (1996) (2007).}


and lack of meaning, revealing the complexity of reality and making it difficult to sustain narratives that favored notions of linearity, proposition and coherence (PAUL 2008, p. 12-13).

Although it did not undermine values and moral beliefs per $\mathrm{se}^{6}{ }^{6}$ the crisis that emerged during this period made it difficult to justify these values in historical terms. This is why, in Paul's words, the crisis of historicism represented the "collapse of trust" that had sustained the coherence of bourgeois discourse since Ranke, Humboldt, and Droysen (PAUL 2008, p. 21). ${ }^{7}$

Moreover, as a problem that arose within the German tradition of historical thought itself, and not having originated in external discussions, as authors like Charles Bambach sustained (BAMBACH 1995, p. 185), Paul suggests regarding the crisis as a subjective genitive: "Only when the (classical) historicist mode of thought began to wane, due to a number of causes, and the order provided by this historicist Weltanschauung began to collapse, space for other, less reassuring worldviews emerged" (PAUL 2008, p. 13).

For people who had learned to see themselves in historical terms and position themselves in genealogical narratives, and who had defined themselves as inheritors of traditions with a future lean, the awareness that history could be dramatically different from what was expected not only destroyed certain versions of the past, but also prevented the formation of historical identities in its most fundamental terms. Hence, the alleged "relativism" experienced at that time by Troeltsch, Meinecke, and Hintze did not mean the absence of universal values as such, but rather the impossibility of their justification in historical narratives.

However, if Paul is quite accurate in dealing with the historicist faith and discursive elements that allowed its sustainability in the nineteenth and early twentieth centuries, I believe the historian fails to identify this belief in its absolute values-of nation, state, culture or religion-as the product of a certain experience within Western modernity.

\begin{abstract}
6 - Paul argues, against Wittkau, that the crisis of historicism did not so much concern the validity of values as such, but, especially after 1918 , the ability of historicism to justify values, ideas of progress and religious belief (WIKLUND 2017, p. 92).
\end{abstract}

7 - This enabled him to grasp that the crisis of historicism was not limited to Germany, but was instead characterized as a broader phenomenon, likely to occur in the most distinct places, moments and cultural realities (PAUL 2010, p. 192). 
After all, more than a homogeneous and predetermined thing, such totalizing pretension present in much of nineteenth and twentieth century European historiographical production was a construction of modern times, anchored, above all, in what Reinhart Koselleck identified as the process of emergence of the concept of history in the modern age.

Therefore, to complement Paul's thesis, it is worth remembering that for Koselleck, in the centuries preceding the advent of modernity in Europe, the main form of experiencing time involved the expectations of salvation and the arrival of the end of the world, so the concept of history (Historie) diffused until then reflected much of the stability and confidence deposited by medieval man in the constancy of human nature (KOSELLECK 2006 , p. 43). Living in the distant expectation of the last judgment, individuals referred to their actions from what nature could offer in terms of temporal experience; it was even possible to extract from history a series of moral lessonshistoria magistra vitae-capable of guiding people's actions.

However, Koselleck notes that this exemplary historical model gradually ceased to have relevance in the imagination of the courts and during the rise of the European bourgeoisie from the eighteenth century onwards. Following numerous factors, including the advance of science and technology, religious wars, the discovery of the New World (which revealed populations living in different stages of development) and the dissolution of the feudal world by industry and capital, this magistra vitae view of history gave way to a new and more comprehensive form of historical conception-History (die Geschichte), understood as a "collective singular", precisely because of its capacity to embrace and consider the whole of humanity and its joint achievements on earth (KOSELLECK 2006, p. 236-237). Driven by the revolutionary events of the eighteenth and nineteenth centuries, the diffusion of this concept of history was most prominent between the 1750s and 1850s, a period Koselleck names Sattelzeit (saddle time, threshold time, or watershed epoch). It was a time of great confidence in universal reason 
and in the human capacity of intervention in time and in the very meaning of this new concept of history (KOSELLECK 2014, p. 281).

Incorporated by the nascent philosophies of history and by nineteenth century historicism, History was henceforth understood as a great march of humanity toward progress and civilization. Shortening spaces of experience and widening the horizons of expectation about the future, this history "in and of itself" (Geschichte an sich) created new categories for understanding human relations and the places occupied by each society and each culture within concepts such as "universal history" (Universalgeschichte) and "world history" (Weltgeschichte) (KOSELLECK 2006, p. 50-51). "[T]he contemporaneity of the non-contemporaneous" established itself as a way of measuring, from a homogeneous reading of the distinct temporal layers, the place occupied by the other in the whole history of humanity. Such categories as "progress", "decadence", "acceleration", and "not yet" served to order and qualitatively classify peoples and cultures, so that the historical science itself originated from the need of understanding and hierarchically organizing nations within that collective singular conception of history (KOSELLECK 2006, p. 121-122).

It was this kind of belief that sustained the European bourgeoisie worldview during modern times until the emergence of more vehement manifestations contrary to its meaning, as with the Nietzschean critiques of history in the late nineteenth century. In other words, it was the modern "collective singular" concept of history that shaped the modes of identity formation underlying historicism. Therefore, to complement Paul's thesis, it is even possible to "provincialize" 8 the crisis of historicism and regard it not only as the waning of a specific way of narrating history and relating to the past, but as the collapse of trust on the very foundations of the Western-centered concept of history that prevailed in the European world at least since the second half of the eighteenth century.

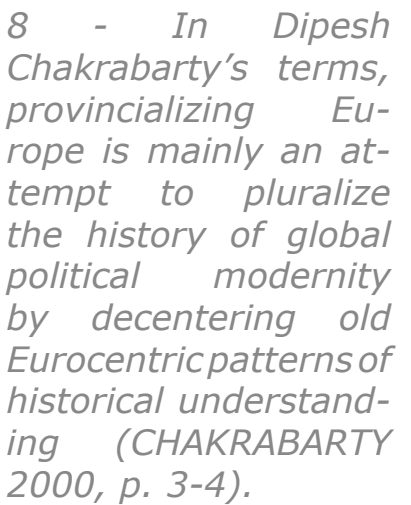
2000, p. 3-4). 
A good way of testing this hypothesis is to shed light on how this crisis emerged within the German historical science itself, by analyzing the strategies taken by historians to overcome what was gradually being seen by some of them as the aporias of this modern conception of history. Hence, a look at the answers offered by Hintze to such a crisis may be useful to understand this process and its unfolding among certain representatives of the German historical sciences during the German Empire and in the Weimar period. To do so, it is necessary to consider specific aspects of the intellectual context in which Hintze's theoretical propositions on historicism emerged.

\section{Hintze's place in the historiography of the German Empire and the Interwar period}

Although many interpreters agree that most German historians remained unresponsive up to the late 1950 s to the above mentioned problems related to modern history, it is wrong to claim that this passivity extended to all representatives of Germany's historical science at the end of the nineteenth and the first decades of the twentieth century. Influenced by factors such as the trauma of war, abrupt sociopolitical changes and, above all, the interdisciplinary debates that occurred at the beginning of the twentieth century, scholars such as Hintze perceived some of the fragilities of Germany's traditional historical science vis-à-vis the cultural and sociopolitical demands of that era.

Born in 1861 in the Pomeranian city of Pyritz, Hintze studied at the University of Berlin in the 1880s, in a time when intellectuals such as Johann Gustav Droysen, Wilhelm Dilthey, and Gustav von Schmoller were teaching in the capital of the German Empire at the height of their intellectual prestige. After graduating in 1885, still in Berlin, Hintze studied six extra semesters of law and public administration with the intention of getting properly prepared to study the themes that would appear at the heart of his work until the end of his career-constitutional and administrative history (OESTREICH 1972, p. 194). 
After finishing his habilitation thesis in 1895, seven years later, young Hintze occupied the chair of administrative, constitutional, and political history in his alma mater. His appointment as professor in the capital of the German Empire was largely due to the publication of a series of papers on the historical, administrative, and constitutional development of the Prussian state since the eighteenth century.

His interests in Prussia and its institutions were in part stimulated by his participation since 1887 in the Acta Borussica project, which under the auspices of the Royal Academy of Sciences and under the supervision of Schmoller published documents and research sources concerning the state and the Hohenzollern monarchy (NEUGEBAUER 1993, p. 66). Unlike the essentially political type of history written by his contemporaries, Hintze treated the Prussian past by considering the broad theme of its institutions and by leaving behind the semi-official tone which was characteristic of the historiography of his time. Even before the outbreak of World War I, Hintze had already clarified that the goals of his historical writing went far beyond a mere official Prussian history: "The real goal of my intellectual endeavors has always been directed at a comparative history of the constitutions and administrations of the West (der Neueren Staatenwelt ${ }^{9}$ )" (HINTZE 1914, p. 746). This broader perspective allowed him to "complement Ranke's work", which, along with his former teachers, was one of his major intellectual influences (HINTZE 1914, p. 746).

His concern with theoretically and methodologically innovating historical research dates back both to his years as a student of Droysen and Dilthey in Berlin and to the beginning of his dialogues with Meinecke in the late 1880 s. These were conversations which inspired the writing of Über individualistische und kollektivistische Geschichtsauffassung (On individualistic and collectivist approaches to history) published by the Historische Zeitschrift in 1897. In this article, Hintze defined his position amid the methodological dispute 
known as Lamprechtstreit (The Lamprecht controversy) that was occurring in German historiography during the 1890s (SCHIEDER 1984, p. 619).

In his monumental Deutsche Geschichte (German History) and in a series of articles and essays, professor of modern and medieval history at the University of Leipzig, Karl Lamprecht declared war on the individualizing and descriptive method of traditional German historiography. Contrary to the political approach and to the Rankean theory of ideas, Lamprecht claimed the establishment of general laws and a broad cultural perspective, capable of reestablishing analytical precision and the scientific character of historical knowledge (LAMPRECHT 1896, p. 71).

It would not be long before Lamprecht's propositions were severely attacked by the leading representatives of the German historical science of that period. After all, in his criticism, the Leipzig professor had not only challenged contemporary historiography, but also the whole tradition of historical thought that prevailed in Germany at least since Humboldt and Ranke. Hence, historians such as Georg von Below and Max Lenz argued in favor of traditional historiography, condemning Lamprecht's cultural history for its flirtation with Western positivism and for the dilettantism of its theoretical-methodological proposals (CHICKERING 1993, p. 146-167).

However, contrary to most historians involved in the Lamprechtstreit, in his On individualistic and collectivist approaches to history, Hintze sought a moderate position vis-à-vis the provocations of the author of German History. Considering Lamprecht's criticisms of idealism and Ranke's idea of individuality, ${ }^{10}$ Hintze meditated on the possible advantages of a reconciliation of this traditional theory with a more comprehensive collectivist approach of historical research. Besides presenting a theoretical consideration of both parts, Hintze pointed to a break with the traditional patterns of nineteenth century historical writing, as well as what henceforth

\begin{abstract}
10 - For historicism the defining subject matter of history, and the goal of historical enquiry, is the individual (even individual totalities), i.e., this or that determinate person, culture or epoch which exists at a specific time and place (BEISER 2011, p. 4).
\end{abstract}


would be one of his major academic interests: "to constitute world history from of a comparative history of the nations" (HINTZE 1897, p. 67).

Avoiding the contemplation of a single object, the comparative analysis of the development of distinct European constitutions and administrative systems allowed Hintze to move away from the exalted nationalism of most historians of his time. Even in works such as Die Hohenzollern und ihr Werk (The Hohenzollern and their work), written on the eve of World War I to celebrate the five hundred years of the Prussian royal dynasty, Hintze kept a certain analytical distance from the subject matter, while opting for a narrative in which institutional development and foreign policy had a more prominent role than the mere achievements of heroes or individual factors alone (KARADY 1965, p. 1291-1292).

Nevertheless, like Troeltsch, Meinecke, Max Weber and most of the liberal German bourgeoisie, Hintze supported the 1914 war and was latter frustrated with imperial Germany's conservative excesses and the country's defeat in 1918. After all, he had believed in the uniqueness of the Prussian historical experience as an analytical standard from which other European states could also be understood. Thereafter, however, Prussia had lost its prominence, and the international political scenario had proven to be much more complex and adverse to the old aspirations of the German monarchy than the historian had previously thought (GILBERT 1975, p. 19-20).

His acceptance of the republican ideal in the postwar years implied the need to reassess old postulations as well as some previous positions regarding his conception of history. With health problems, including a serious eye illness, Hintze retired from his professorship at the University of Berlin in 1920. These issues also contributed to the beginning of a new phase in his career. Prevented from reading documents and primary sources, the historian started to write a series of articles, book reviews, and essays in which he expressed some of his views on the philosophy, theory, and methodology of history. ${ }^{11}$

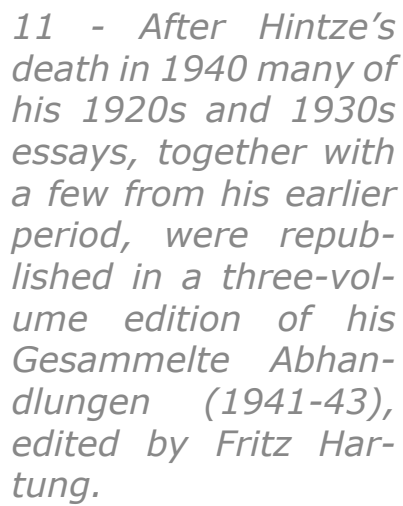

11 - After Hintze's death in 1940 many of his 1920 s and 1930s essays, together with a few from his earlier period, were republished in a three-volume edition of his Gesammelte Abhandlungen (1941-43), tung. 
In these he dealt with much of the literature concerning the complex situation experienced in German culture and thought during the Weimar Republic. Dialoguing with names such as Max Scheler, Hans Kelsen, Franz Oppenheimer, Troeltsch and especially Max Weber, Hintze discovered the epistemological foundations that enabled him to renew his project of writing a comparative history of European constitutions and states (IGGERS 1983, p. 233-234).

Hitler's rise in 1933, however, prevented the continuation of most of his intellectual projects, and his manuscripts remained unpublished at least until the end of World War II. The persecution of his wife, Hedwig Hintze, ${ }^{12}$ and his deep discontent with the National Socialist regime forced Hintze to live a secluded and solitary life in Berlin. Even after his death in 1940 and at least until the first decades of the postwar period, ${ }^{13}$ his theoretical writings remained unknown in Germany and were restricted to a reduced circle of intellectuals. However, among those influenced by Hintze's ideas were his friend Meinecke and some of his disciples like Felix Gilbert ${ }^{14}$ and Dietrich Gerhard who, after emigrating to the USA during the Nazi era, became very influential historians (SCHIEDER 1984, p. 616).

Besides his theoretical contributions to what would later be considered a structural type of social history, Hintze also played an important role in the 1920 s controversy over the previously mentioned crisis of historicism. Although a peripheral issue for most of Hintze's specialized literature, previous research already focused on the historian's reaction to the problems of historicism. Works like Wittkau's (1992) and Oexle's (1996), for example, dealt with Hintze's participation in the Histotismusdebatte, regarding the historian's contributions as responses to the crisis of historicism, which Wittkau describes as "the relativizing tendency of the historical discipline" that questioned its possibility as a "practice-oriented science", which affected all Western Kulturwissenchaftliche disciplines during the nineteenth and the twentieth centuries (WITTKAU 1992 , p. 11). Oexle, in his turn, has even defined historicism

\begin{abstract}
12 - Married to Hintze (her former professor) since 1912, Hedwig Hintze was one of the first female historians in Germany. She finished her PhD in 1924 and occupied important positions in the intellectual circles of the Weimar Republic (OESTREICH 1985, p. 397-419).
\end{abstract}

13 - It was only during the 1960s that Hintze's collected essays (Gesammelte Abhandlungen) were again published in three volumes by Gerhard Oestreich.

14 - Gilbert was the main responsible for editing the first English translation of Hintze's essays, which appeared in 1975 as The historical essays of Otto Hintze. 
itself as the "fundamental historicization of our knowledge and thought" or "the insight that everything has historically come into being" (OEXLE 1996, p. 17). Thus, historicism, in their account, is not the historical tradition represented by Humboldt and Ranke, but a worldview that begun permeating the everyday lives of educated Western European citizens. Why, for Oexle and Wittkau, Hintze's participation in such a quarrel-mainly through his Weberian redefinition of historicism as a "logical mind-structure category" (OEXLE 1996, p. 60; WITTKAU 1992, p. 174)-can be regarded as an objective genitive interpretation of the crisis of historicism, that is, a crisis caused by historicism (rather than as a crisis faced by the historicist tradition) (LAUBE 2004, p. 11). However, I believe that the Oexle-Wittkau approach is much too narrow in its attempt to grasp Hintze's response to such a crisis, (1) for its failure to regard the crisis of historicism mainly as a subjective genitive (which was above all, as already described above, a crisis faced by the historicist tradition itself) and (2) for its interpretation of the Historismusdebatte strictly as an academic affair. ${ }^{15}$ In other words, the Oexle-Wittkau approach fails to perceive how the crisis of historicism was a much broader cultural problem that reflected a break in the historical self-experience of middleclass society and caused the collapse of trust on the very foundations of Western-centered forms of narrating history. Thus, is through the lens of such a broader redefinition that Hinze's contributions-especially in his discussion of Meinecke, Troeltsch, and Weber ideas-should be assessed.

Therefore, to sustain such a view, I will discuss in the following sections some of the historian's insights on the problems of historicism by first dealing with Hintze's critical reevaluation of some of the most central ideas within Germany's tradition of historical thought; namely, the meaning of politics and the concept of state.
15 - Authors like Wolfgang Hardtwig (1991), Friedrich Jaeger (1996) and Herman Paul (2008) (2010) (2010b) agree that the crisis of historicism can't be read as a narrow academic affair (which affected only an intellectual elite), but as a broad cultural problem. 


\section{Hintze and the desacralization of modern state politics}

Most of Hintze's work interpreters agree that one of the main dissonances of his ideas in comparison to most of the historical thought of his time was his critique of the historical ideal of individuality. Unlike his predecessors, the Prussian Historical School and his contemporaries, the Neo-Rankeans, Hintze recognized very early in his career the limits of a genetic type of historical theory in which the interest of the individual nation state tended to prevail over factors and explanations of a broader order:

The impact of the outside world must pass through an intellectual medium (...). With this reservation we can-indeed, must-stress that in peoples' life external events and conditions exercise a decisive influence upon the internal constitution. History does not permit progressive spiritual development, following its own laws, as was supposed by Hegel; there is rather a constant collaboration and interaction of the inner and outer world (HINTZE 1975, p. 162).

This claim about the various "impulses and pressures" (Schieben und Drängen) that influenced the historical course of the modern nation states led him to embrace a comparative perspective in understanding the genesis of the different European constitutions and administrative systems. ${ }^{16}$ If Hintze had retained his confidence in the Prussian model as a sort of universal analytical standard at least until the end of World War I, the postwar years made him more skeptical, not only of Prussia, but also of the broader meaning of the state and its role in the development of universal history as a whole. The historian expressed such a change in his conception about ethics and politics in essays such as Soziologische und geschichtliche Staatsauffassung (Sociological and historical conceptions of the state) (1929) and Weltgeschichtliche Bedingungen der Repräsentativverfassung (The Preconditions for Representative Government in the Context of World History) 
(1931), written at the time of his theoretical reflections of the 1920s and 1930s.

Influenced by Weberian thought, Hintze started to understand modern institutions within the ambiguous process of rationalization experienced by Western civilization. Thus, the state was no longer seen as containing a life of its own, existing independently and above contradictions and social groups; it became, on the contrary, a mere institutional apparatus, changing its functions and its proposals based on external circumstances and changes in the distribution of power (GILBERT 1975, p. 22).

Far from being in tune with universal ethics and being conceived as an end in itself, the modern nation state now existed at the mercy of the whims of international politics, and its destiny was now related with phenomena such as imperialism and the search for overseas colonies: "every power, at least every preponderant power, is generally used in an unreasonable way, being used in an erroneous way even considering its moral and legal formulations" (HINTZE 1929, p.38-39).

This submission of universal history to the dictates of political power, established by real men and institutions, was Hintze's way of complementing both the idealism of the Rankean perspective and the rationalism of Weber's sociological theory. Hintze incorporated the Weberian use of ideal types and abandoned the old historical-idealist belief in a predetermined sense of history, while also leaving behind the possibility of a mimetic apprehension of the "ideas" that guided the past:

An eternal world of ideas, existing above and beyond human life, and offering an occasional revelation to humanity, is an assumption incompatible with the nature of the ideas that emerge in history (HINTZE 1927, p. 217). 
Ideas limited their existence to the individual human mind, serving more as a heuristic instrument of reality analysis than as an empirical confirmation of past trends. This expansion of the theoretical range and of the very notion of individuality, which Hintzeassociated with the Western nation state system as a whole, represented what Leonard S. Smith claimed to be the culmination of a secularization process experienced within parts of German historical thought in the first half of the twentieth century. Rationalizing state and politics, comparing different historical developments and clarifying the distance between conceptual formulations and historical reality, Hintze embraced an immanent conception of history in which the understanding of the world was restricted to the limits of the elementary human condition in modern times (SMITH 2010, p. 250).

However, unlike Troeltsch and even Weber, Hintze was not distressed by the possible consequences of this desacralized historical perspective. Even with the great number of diagnoses that pointed to a crisis of historicism arising from relativism and the dissolution of old values, the historian maintained his confidence in the human capacity to produce statements and practical guidelines for society in the present. This conviction stemmed from a specific characteristic of Hintze's thought that accompanied him since the beginning of his career; namely, his confidence in the possibilities of scientific historical knowledge. Such a perspective is clear in the historian's critique of the Troeltschean concept of historicism, which is precisely the theme of the next topic.

\section{Hintze and the scientific character of historical knowledge as a solution to the crisis of historicism}

Hintze summarized much of his theoretical conceptions and his position in the debates on historicism in Troeltsch und die Probleme des Historismus (Troeltsch and the problems of historicism), an essay published in 1927 in the Historische 
Zeitschrift. In this text, besides discussing some of Troeltsch's ideas, the historian formulated what he believed was the correct direction the German historical science should take to overcome some of the challenges posed by the first decades of the twentieth century.

Although he saw the merits of Troeltsch's efforts to surpass the contradictions of science and modern Western historical consciousness, Hintze believed that the theologian had failed in his attempt to provide historicism with a positive meaning, thereby failing to contribute to overcome its alleged crisis. This was largely because the author of Der Historismus und seine Probleme (Historicism and its problems) (1922) confused two essential scopes of the historicist problem; its ethical and epistemological dimensions:

This definition places an emphasis on historicism as methodology, but it does not clearly separate this aspect of historicism from a concept of it as a general philosophy of life. These two ideas are, of course, related, but it still seems to me both desirable and possible to draw a distinction between them (HINTZE 1927, p. 190-191).

More than a simple conceptual mistake, Troeltsch's confusion between worldview and epistemology (or between ethics and science) led to many paradoxes that made it impossible for him to solve the so-called problems of historicism, that is, skepticism, immobilism, values relativism, etc. Thus, in his essay Hintze sought to clarify the points left open by the theologian, aiming to establish a truly positive meaning for the concept of historicism (KÄMMERER 2014, p. 94).

First and foremost, Hintze sought to clarify that historicism had nothing to do with a worldview. In his terms, historicism represented much more a "way of thinking" or a "set of methodological categories" that, far from being an exclusively German phenomenon, ${ }^{17}$ had gradually evolved in the Western world since the eighteenth century. This led him to a

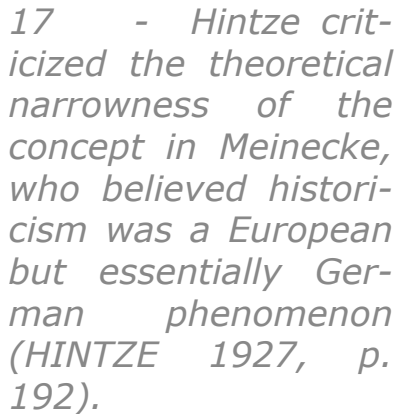

192). 
broader definition which included positivism and Marxism as representatives of historicist thought trends, abandoning the traditional idea of individuality in favor of an understanding of historicism as a far-reaching Western development (HINTZE 1927 , p. 192). While eliminating the notion of worldview and emphasizing the concept's epistemological aspect, Hintze simultaneously restricted and expanded his understanding of historicism. This implied necessarily approaching the phenomenon from a perspective he believed underestimated by the Troeltschean approach; namely, the scientific features of historicist thought. In his analysis, Hintze sought to eliminate what he believed was the religious optimism that had prevented the theologian from properly exploring the epistemological possibilities of the historical understanding (SMITH 2010, p. 243).

Hintze thus claimed that one of the main misunderstandings in Troeltsch's alleged "mysticism" occurred in its mix of the notions of value and meaning. Although he agreed that the historian's work invariably began in the realm of intuitions (as "a value for life") for example, in the choice of an individual object, Hintze believed that historical research should never end in the sphere of values or in what he identified as the units of meaning with an individual character (OEXLE 1996, p. 60). In other words, and talking in Weberian terms, Hintze proposed a drastic separation between what he believed to be the sphere of life and the objectivity of scientific knowledge:

The historical object as individual totality, then, is grasped intuitively as a unit of life. It is the task of rational inquiry, employing empirically gathered materials, to demonstrate the unity of meaning in the historical object. Any relation to a value structure is general and incidental, since all life and all cultures have some kind of inherent values, and it is only in this general sense that values bear on the delimiting of an object of historical study (HINTZE 1927, p. 206). 
Although they originate in the human experience of life, concepts such as individuality and development, for example, did not find immediate expression and therefore, should not operate as determinants of a priori ethical directions. Instead, concepts should work as heuristic abstractions (thus never merging with historical reality itself) responsible for enlightening fragments of reality that, only after rational scrutiny, should then point to actual social tendencies and realizations (KOCKA 1981, p. 96).

It was precisely for denying the distance between ideas and reality, and even between the understanding of logics and the philosophy of history, that, in Hintze's words, Troeltsch succumbed to the pitfalls of mysticism. While admitting that historical science could never completely eliminate the mysteries of historical things, Hintze believed that the historian should do as much as possible to clarify the obscure aspects of the past: "I do not mean to deny the mysterious and inexplicable aspects of creative production. The famous $X$ of Droysen remains, but in my view historical research should reduce this $X$ to a minimum" (HINTZE 1927, p. 218).

Despite disagreeing with Troeltsch's philosophy of history and its epistemological logic, Hintze agreed with the theologian about the urgency of relating historical knowledge with the practical demands of present day society. For the historian, Troeltsch was right to associate the problem of historicism with the task of understanding the importance of cultural transfers in the post-1918 world. While denying Oswald Spengler's thesis and demonstrating the growing influence of Western culture on the world, ${ }^{18}$ the theologian had indicated the necessary stimulus of an "ethical will" capable of overcoming the contradictions of an increasingly complex reality both in terms of culture and politics.

Again, Hintze agreed with Troeltsch's diagnosis; however, he disagreed with the solutions of his so-called material philosophy of history. In its quest for ethical standards, the Troeltschean cultural synthesis committed the mistake of seeking for ultimate answers to the insoluble question of values in history. 
Aiming to escape the normativity of an absolute ethics in the manner of Heinrich Rickert, the theologian's emphasis on the ethical impulses of Western culture kept him anchored to the naive optimism of his religious faith, preventing him from paying attention to what Hintze saw as the only real possible means of overcoming the contradictions of historicism-the enlightening potential of historical understanding (TESSITORE 2005, p. 76-77).

Troeltsch's lack of attention to the fundamental problem of the cognitive logics, or of a "psychology of the human sciences" in Hintze's terms, had prevented him from realizing how the independence of spontaneous activity of the individual consciousness could contribute to overcoming the aporias of historical thought. Moreover, his confusion between life and epistemology led him to exaggerate the dimension of the crisis of historicism, ${ }^{19}$ since his fear of historical relativism was largely because of his inability to perceive the liberating potential of individual consciousness vis-à-vis such pernicious forms of worldview:

If we avoid this specific view, we can safely admit the boundless relativity of all historical life without falling prey to relativism or sacrificing the freedom of the spirit. For freedom is basically nothing more than the consciousness of freedom. To be sure, the recognition of both general relativity and individual freedom implies an antinomy. But this antinomy between necessity and freedom is neither more nor less than the riddle of human existence itself and the source of all philosophical dialetic (HINTZE 1927, p. 238).

This clarity about the possibilities of consciousness and historical understanding should also be the key to criticize and to encourage the growth of elements of collective traditions:

If we can do this, we can initiate a movement that will involve material and intellectual forces and that will prevent our culture from degenerating in terms of a purely technical, scientific, and materialistic 'civilization' (HINTZE 1927, p. 238).
19 - Although concerned with a solution to the problems pointed out by the theologian, Hinze's own definition of the crisis of historicism (mainly as values relativism) was one that regarded it as an exaggeration derived from Troeltsch's blur between science and worldview. 
Therefore, instead of a confused and subjective cultural synthesis, Hintze proposed a reconceptualization of historicism which, by setting it free from metaphysics, would be able to clarify historical processes and cultural transfers responsible for the future development of the constituents of Western tradition (GERHARD 1970, p. 43). At its core was the idea that history should be a science oriented towards understanding reality (Wirklichkeit), which, in the complexification and problematization of the real, could reveal interests and point to practical possibilities in the present time. For the historian, this meant understanding the difficulties and problems of contemporary political and economic life, as well as the difficult place occupied by Germany in a world torn between the extremes of Western imperialism and the obscurity of the socialist East. Thus, Hintze claimed that it was precisely such a sense of reality that Troeltsch's philosophy of history and the history of ideas proposed at the same time by Meinecke lacked. Against the wind castles of an idealism concerned with the establishment of ultimate goals and values, Hintze preferred to resort to a historical science capable of stimulating an individual ethical will or what he understood as a "healthy" and "volitional" kind of decisiveness:

It does not lead us to the intellectual absolutism that Rickert had in mind but commits us, if I may say, to a healthy volitional decisiveness (zu einem gesunden, willensmäßigen Resolutismus), to clear cultural aims, to the firm resolution not to surrender the individual, national, and supranational forms of our cultural life, but to stand our ground against all hostile powers and to develop according to our nature (HINTZE 1927, p. 239).

However, despite its emphasis on reason, Hintze's inheritance of the Weberian theoretical position and its hesitancy to merge values with science also signified the need to deal with the limits of its formal logic. Thus, as perceived by Wolfgang Kämmerer, for its rejection of long-term ethical propositions and for its separation of historical science and the realm of worldviews, Hintze's strictly scientific 
historicism left him trapped in a decisionism similar to the one generated by the Weberian ethics of responsibility (KÄMMERER 2014, p. 98).

Similarly, despite his concern for the meaning of cultural transfers, Hintze's rationalism prevented him from defining a solid political agenda and disallowed him to establish the cultural links that would unite Germany with both the Western and non-Western worlds. Moreover, unlike the Troeltschean notion of Europeanism ${ }^{20}$, Hintze did not produce a concept that permitted him to think of cultural exchanges beyond the reiteration of the European values and their overlap with other non-Western world cultures. ${ }^{21}$

However, such limitations did not prevent Hintze's ideas from playing a relevant role in subsequent discussions on the nature of the historical discipline in Germany. Although restricted to a narrow audience, Hintze's will to renew the historical science reveals the depth of the debates on the crisis of historicism of that era and points to an important direction which was followed by certain segments of German historiography when the ethical and epistemological boundaries of the modern Western-centered concept of history were no longer being ignored.

\section{The echoes of the crisis of historicism and the actuality of Hintze's historical thought}

As a result of abrupt changes brought on by war and industrialization, the late nineteenth and the early twentieth centuries were marked by a deep crisis which affected the practical guidance of some bourgeois circles and Germany's society during that period. Synthesized by Troeltsch as the crisis of historicism, as described above, a whole set of aporias gradually revealed the fragilities of long-held beliefs in the absolute values of nation, state, religion, and culture, which had prevailed in the historical imagination of German bourgeoisie until that time. That is why, following Herman Paul's steps, the

\begin{abstract}
20 - To overcome historiography's ethnocentrism, Troeltsch formulated the concept of Europeanism, a decentralized type of historical outlook which could foster, through the lens of otherness, Europe's own cultural legacy (HARRINGTON 2004, p. 486).

21 - Gerhard notices that Hintze's work was a contribution to universal history in Eurocentric terms. It was the history of the West, only by way of contrast were other civilizations considered (GERHARD 1970, p. 46).
\end{abstract}


crisis of historicism was defined in this essay as the collapse of the old belief in the notions of continuity, linearity, and historical sense that had for decades justified the values and formed the identity of members of the German literate middle classes.

As a result of the collapse of trust in the very foundations acquired by the European experience in modern times, I claimed that in various aspects the crisis of historicism can be understood as a moment in which the Western-centered way of understanding history in modernity, as a singular collective in Koselleck's terms, gradually collapsed. Meaning that the old homogeneous way of measuring temporal layers and heterogeneous historical experience suffered severe shocks, so that it became increasingly difficult to coherently justify the superiority of the European civilization using the traditional historical narratives of classical historicism.

This reinterpretation of the crisis of historicism allowed me to shed new light on the position occupied by authors like Otto Hintze in such controversy. Thus, the historian's theoretical restlessness, his search for interdisciplinarity, his emphasis on comparative history, and, above all, his desacralization of modern state politics were regarded as strategies undertaken to overcome the limits of classical historicism and as attempts to adapt the postulations of the historical science to the new global socio-political dynamics of the twentieth century.

Hence, I intended to confirm this hypothesis with a deeper analysis of Hintze's contributions to the struggle on the very definition of the concept of historicism which had been reopened by Troeltsch in the World War I years. While criticizing the Troeltschean definition, Hintze believed that a solution to the problems of historical relativism was the need to eliminate the elements of Weltanschauung present in the concept of historicism. By distinguishing historicism from a mere worldview and highlighting the freedom of choice of rationally-oriented individuals, Hintze thought possible to extol the epistemological aspects of historicism; drawing from it the scientific rigidity necessary to overcome the dilemmas posed 
by the modern idea of history to Western civilization values. Likewise (and despite his underestimation of the crisis), his "healthy volitional decisiveness" combined with "scientific" historical knowledge can be regarded as Hintze's means of overcoming the collapse of trust in the old traditional values held by German middle classes and as his solution, in terms of a practical guidance, to the ethical problems faced by parts of German society during the Interwar period.

Therefore, if one considers the numerous discussions that arose among professional historians in the last several decadesthe fragmentation of history, the fragilities of the traditional Cartesian epistemology, the so-called presentist immobilism, and the ethnocentric limits of the historical discipline-one is able to claim, with no risk of exaggeration, that, far from being outdated, the crisis of historicism continues to produce important echoes for contemporary historical thought. Similarly, if one considers that these misfortunes have been unable to substantially undermine the problems brought on by such a modern Western-centered conception of history, one can suggest that Hintze's historical thinking can still be revisited as a means of producing answers to the dilemmas historiography faces today.

After all, Hintze's theoretical restlessness and reconceptualization of historicism aimed at complexifying elements of the real and producing a critical scrutiny vis-àvis pre-established all-encompassing standards of historical development. Thus, it is safe to say that Hintze's insights remain in the order of the day if one wishes to reflect on the limits of the modern concept of history and on the ethical dimension of the historian's work, as is the case with recent debates on the practical past ${ }^{22}$, which continue in twenty-first century historiography. 
BAMBACH, Charles R. Heidegger, Dilthey, and the crisis of historicism. Ithaca: Cornell University Press, 1995.

BEISER, Frederick C. The German historicist tradition. New York: Oxford University Press, 2011.

BIALAS, Wolfgang. Die Historismusdebatte in der Weimarer Republik. Frankfurt am Maim: Peter Lang, 1996.

CHAKRABARTY, Dipesh. Provincializing Europe: Postcolonial Thought and Historical Difference. Princeton: Princeton University Press, 2000.

CHICKERING, Roger. Karl Lamprecht: a German academic life (1856-1915). New Jersey: Humanities Press International, 1993.

$\mathrm{CHO}$, Joanne Miyang. Historicism and Civilizational Discontinuity in Spengler and Troeltsch. Zeitschrift für Religions- und Geistesgeschichte, v. 51, n. 3, Brill, 1999.

GERHARD, Dietrich. Otto Hintze: His Work and His Significance in Historiography Central European History, v. 3, n. 1/2, Cambridge University Press, 1970.

GILBERT, Felix. Introduction: Otto Hintze (1861-1940). In: HINTZE, Otto. The Historical Essays of Otto Hintze. New York: Oxford University Press, 1975.

HARDTWIG, Wolfgang. Geschichtsreligion-Wissenschaft als Arbeit-Objektivität. Historische Zeitschrift, v. 252, n. JG, p. 1-32, 1991. 
HARRINGTON, Austin. Ernst Troeltsch's concept of Europe. European Journal of Social Theory, v. 7, n. 4, p. 479498, 2004.

HINTZE, Otto. "Antrittsrede des Hern. Hintze". In: Sitzungsberichte der Königlich Preußischen Akademie der Wissenschaften zu Berlin. Berlin: Verlag der Königlichen Akademie der Wissenschaften, 1914.

HINTZE, Otto. Gesammelte Abhandlungen. Edited by Fritz Hartung, 3 vols. Leipzig: Koehler \& Amelang, 1941.

HINTZE, Otto. Soziologische und geschichtliche Staatsauffassung. Zu Franz Oppenheimers System der Soziologie. Zeitschrift für die gesamte Staatswissenschaft, Bd. 86. Tübingen: Mohr Siebeck GmbH \& Co, 1929.

HINTZE, Otto. The formation of states and constitutional development: a study in history and politics. In: HINTZE, Otto. The Historical Essays of Otto Hintze. New York: Oxford University Press, 1975.

HINTZE, Otto. The Preconditions of Representative Government in the Context of World History. In: HINTZE, Otto. The Historical Essays of Otto Hintze. New York: Oxford University Press, 1975.

HINTZE, Otto. Troeltsch und die Probleme des Historismus. Historische Zeitschrift, v. 135, n. 2, 1927.

HINTZE, Otto. Über individualistische und kollektivistische Geschichtsauffassung. Historische Zeitschrift. Bd. 78, R. Oldenbourg, München und Leipzig, 1897.

IGGERS, Georg. Historicism: The History and Meaning of the Term. Journal of the History of Ideas, v. 56, n. 1, 1995. 
IGGERS, Georg. The German Conception of History: The National Tradition of Historical Thought from Herder to the Present. Rev. ed. Middletown, Conn.: Wesleyan University Press, 1983.

JAEGER, Friedrich. Theorietypen der Krise des Historismus. In: BIALAS, Wolfgang; RAULET, Gérard. Die Historismusdebatte in der Weimarer Republik. Frankfurt am Maim: Peter Lang, 1996.

JAEGER, Friedrich; RÜSEN, Jörn. Geschichte des Historismus: eine einführung. München: CH Beck, 1992.

KÄMMERER, Wolfgang. Friedrich Meinecke und das Problem des Historismus. Frankfurt: Peter Lang $\mathrm{GmbH}$, Internationaler Verlag der Wissenschaften, 2014.

KARADY, Viktor. La théorie de l'histoire et de la société selon Otto Hintze. Annales. Histoire, Sciences Sociales, 20e Année, n. 6, 1965.

KOCKA, Jürgen. Otto Hintze, Max Weber und das Problem der Bürokratie. Historische Zeitschrift, Bd. 233, H. 1, Oldenbourg Wissenschaftsverlag, München, 1981.

KOSELLECK, Reinhart. Estratos do tempo: estudos sobre a história. Rio de Janeiro: Contraponto / Ed. PUC-Rio, 2014.

KOSELLECK, Reinhart. Futuro passado: contribuição à semântica dos tempos históricos. Rio de Janeiro: Contraponto / Ed. PUC-Rio, 2006.

LAMPRECHT, Karl. Alte und neue Richtungen in der Geschichtswissenschaft. Deutsche Zeitschrift für Geschichts-wissenschaft, v. 97, Paul Siebeck, Berlin, 1896. 
LAUBE, Reinhard. Karl Mannheim und die Krise des Historismus: Historismus als wissenssoziologischer Perspektivismus. Göttingen: Vandenhoeck \& Ruprecht, 2004.

MARTINS, E. C. R. Historicismo: o útil e o desagradável. In: VARELLA, Flávia F.; MOLLO, Helena M.; MATA, Sérgio R. da; ARAÚJO, Valdei L. de. (Org.). A dinâmica do Historicismo. Revisitando a historiografia moderna. 1ed. Belo Horizonte: Argumentum, 2008.

MEINECKE, Friedrich. Zur Theorie und Philosophie der Geschichte. Werke IV. Stuttgart: KF Koehler Verlag, 1959.

NEUGEBAUER, Wolfgang. Otto Hintze und seine Konzeption der Verfassungsgeschichte. Zeitschrift für Historische Forschung, v. 20, n. 1, p. 65-96, 1993.

NEUGEBAUER, Wolfgang. Otto Hintze: Denkräume und Sozialwelten eines Historikers in der Globalisierung 18611940. Paderborn: Schöningh Paderborn, 2015.

OESTREICH, Brigitta. Hedwig und Otto Hintze. Eine biographische Skizze. Geschichte und Gesellschaft, v. 11, n. H. 4, p. 397-419, 1985.

OESTREICH, Gerhard. Hintze, Otto. In: Neue Deutsche Biographie. Berlin: Duncker und Humblot, 1972.

OEXLE, Otto Gerhard. Geschichtswissenschaft im Zeichen des Historismus: Studien zu Problemgeschichten der Moderne. Vandenhoeck \& Ruprecht, 1996.

OEXLE, Otto Gerhard. Krise des Historismus - Krise der Wirklichkeit. Wissenschaft, Kunst und Literatur 1880-1932, Vandenhoeck \& Ruprecht, 2007.

PAUL, Herman J. A collapse of trust: Reconceptualizing the crisis of historicism. Journal of the Philosophy of History, v. 2, n. 1, p. 63-82, 2008. 
PAUL, Herman. Religion and the Crisis of Historicism: Protestant and Catholic Perspectives. Journal of the Philosophy of History, v. 4, n. 2, p. 172-194, 2010.

PAUL, Herman. Who Suffered From The Crisis of Historicism? A Dutch Example. History and Theory, v. 49, n. 2, p. 169-193, 2010b.

SCHIEDER, Theodor. Otto Hintze und die moderne Geschichtswissenschaft. Historische Zeitschrift, Bd. 239. Berlin: Oldenbourg Wissenschaftsverlag, 1984.

SMITH, Leonard S. Religion and the Rise of History: Martin Luther and the Cultural Revolution in Germany, 1760-1810. Cambridge: James Clarke \& Co, 2010.

SMITH, Leonard S. The Expert's Historian: Otto Hintze and the Nature of Modern Historical Thought. Wipf and Stock Publishers, 2017.

TESSITORE, Fulvio. Kritischer Historismus: gesammelte Aufsätze. Böhlau, 2005.

TROELTSCH, Ernst. Die Krisis des Historismus. Die neue Rundschau, v. 33, n. 1922, p. 572-90, 1922.

WHITE, Hayden. The practical past. Evanston: Northwestern University Press, 2014.

WIKLUND, Martin. Rüsen's response to the crisis of historicism. Intelligere, Revista de História Intelectual, v. 3, n. 2, 2017.

WITTKAU, Annette H. Historismus zur Geschichte des Begriffs und des Problems. Göttingen: Vandenhoeck \& Ruprecht, 1992. 


\section{AUTHOR NOTE}

\section{Marcelo Durão Rodrigues da Cunha}

marceloduraocunha@gmail.com

Postdoctoral researcher at Adam Mickiewicz University (AMU)

Instituto Federal do Espírito Santo

Colatina

Espírito Santo

Brasil

\section{CORRESPONDENCE ADDRESS}

Marcelo Durão Rodrigues da Cunha

Instituto Federal de Educação, Ciência e Tecnologia do Espírito Santo, Unidade Vitória.

Avenida Rio Branco - de 2 a 402 - lado par

Santa Lúcia

29056264

Vitória, ES - Brasil

\section{ACKNOWLEDGMENT AND OTHER INFORMATIONS}

The article derives from the thesis "A história em tempos de crise: Friedrich Meinecke (1862-1954) e os problemas do historicismo alemão" and presents substantial advances in relation to the mentioned text.

\section{FUNDING}

The research leading to this publication has received funding from the Foundation for Polish Science (FNP), Team Program, the "Core Concepts of Historical Thinking" Project, grant no POIR.04.04.00-00-5C1E17-00.

I thank Instituto Federal do Espírito Santo for the financial support for the translation of this article.

\section{CONFLICT OF INTEREST}

No potential competing interest was reported by the authors.

Copyright

2020 História da

Historiografia: International Journal of Theory and History of Historiography. This is an Open Access article distributed under the terms of the Creative Commons License AttributionNonCommercialNoDerivatives $\quad 4.0$ International License. 